\title{
PENYULUHAN UPAYA PENANGGULANGAN DAN PEMERIKSAAN CACINGAN SEBAGAI IMPLEMENTASI PROGRAM PESANTREN SEHAT
}

\author{
Atwazzah, Ria Hapsari, Iman Surya Pratama, Siti Rahmatul Aini, Galuh Tresnani, \\ Bambang Fajar Suryadi \\ Universitas Mataram, Mataram, Indonesia \\ atwazahtaisiribrahim@gmail.com
}

\begin{abstract}
Abstrak: Angka prevalensi cacingan nasional pada tahun 2015 sebesar 28,12\%, dengan prevalensi daerah yang bervariasi hingga melebihi $50 \%$. Survey cacingan pada sampel anak SD/MI di Kabupaten Lombok Barat pada tahun 2011 menunjukkan angka prevalensi 29,47\%. Cakupan upaya penanggulangan yang masih terbatas mendorong peningkatan koordinasi lintas mitra salah satunya pesantren. Program pengabdian kepada masyarakat ini bertujuan untuk mengimplementasikan upaya penanggulangan cacingan melalui penyuluhan dan demonstrasi indikator Perilaku Hidup Bersih dan Sehat (PHBS) pada salah satu mitra pondok pesantren di daerah Lombok Barat. Metode pengumpulan data yang digunakan yaitu wawancara semi terstruktur dan observasi pengetahuan siswa dengan lembar kuisioner. Berdasarkan pemeriksaan natif terhadap 38 sampel feses terdapat 3 orang cacingan $(0.7 \%)$ terdiri atas infeksi campuran cacing tularan tanah (Ascaris sp dan Trichuris sp) dan infeksi tunggal (Hymenolepis sp, Ascaris sp). Hasil pengabdian secara umum berkontribusi terhadap penguasaan indikator PHBS sederhana yang terdiri atas: Cuci Tangan Pakai Sabun (CTPS), penggunaan alas kaki, serta pengukuran berat, dan tinggi badan secara berkala.
\end{abstract}

Kata Kunci: cacingan; pesantren sehat; PHBS

\begin{abstract}
The national worm prevalence rate in 2015 was 28.12\%, with regional prevalence varies over $50 \%$. Worms survey in a sample of elementary school children in West Lombok Regency in 2011 showed a prevalence rate of $29.47 \%$. The limited scope of prevention efforts has led to increased coordination across partners including pesantren. This community service program aimed to implement the prevention of intestinal worms through counseling and demonstration of clean and healthy behaviors (PHBS) indicators at one of the boarding schools in West Lombok. The methods used in this program is semi-structured interview and observation of students' knowledge with questionnaire sheets. Based on the native examination of 38 feces samples, there were three students who have worms (0.7\%) consisting of mixed infection of earthworm (Ascaris sp and Trichuris sp) and single infection (Hymenolepis sp, Ascaris $s p)$. Generally, this program contributes to the mastery of simple PHBS indicators consisting of: handwashing with soap (CTPS), footwear use, and periodic weight and height measurements.
\end{abstract}

Keywords: worm infestation; healthy boarding school; personal hygiene

\section{Pendahuluan}

Cacingan merupakan penyakit menular yang masih menjadi masalah kesehatan masyarakat Indonesia, tak terkecuali di provinsi Nusa Tenggara Barat (NTB). Angka prevalensi cacingan nasional tergolong sedang dengan angka 28,12\%. Survei prevalensi tahun 2011 menunjukkan angka 29,47\% dan 24,53\% berturut-turut di Kabupaten Lombok Barat dan Mataram (Kementerian Kesehatan, 2012). Sedangkan survei cacingan yang dilakukan Kementerian Kesehatan tahun 2018 di Kabupaten Lombok Tengah menunjukkan 54 sampel positif dari 330 sampel feses $(16,36 \%)$ dengan intensitas askariasis, trikuriasis, infeksi cacing tambang dan enterobiasis termasuk dalam kategori ringan (Kementerian Kesehatan, 2018a). 
Faktor penyebab kejadian cacingan umumnya diakibatkan kemiskinan serta kurangnya sanitasi dan kebersihan seperti berjalan tanpa alas kaki, tidak mencuci tangan dengan sabun sebelum makan dan setelah buang air besar. Kejadian cacingan dapat menular pada suatu individu melalui kontak dengan tanah yang terkontaminasi (cacing tambang) ataupun melalui konsumsi makanan yang terkontaminasi telur cacing (Anuar, Salleh \& Moktar, 2014).

Cacingan berdampak pada penurunan penyerapan zat gizi semisal karbohidrat, protein dan menyebabkan kehilangan darah. Gizi merupakan salah satu faktor yang dibutuhkan anak untuk menunjang pertumbuhan otak atau intelegensia dan tumbuh kembang yang optimal. Anak usia sekolah yang terdampak cacingan dapat lebih rentan terkena penyakit seperti anemia, kondisi fisik berkurang, gangguan perkembangan kognitif, gangguan pertumbuhan, hingga malnutrisi yang diakibatkan oleh penghisapan darah dan zat-zat makanan oleh cacing yang dibutuhkan tubuh (Anuar, dkk., 2014). Angka Global Disability Adjusted Life Years Lost (Global $D A L Y$ 's Lost) mencapai 39 juta menunjukkan potensi penurunan produktivitas sumber daya manusia jangka panjang (Kementerian Kesehatan, 2017).

Kebijakan program penanggulangan cacingan berdasarkan Peraturan Menteri Kesehatan Republik Indonesia No. 15 Tahun 2017 tentang penanggulangan cacingan dititik beratkan di tingkat Kabupaten/Kota dikoordinasikan dengan Dinas Kesehatan setempat dengan mengutamakan upaya preventif-promotif. Upaya ini dapat dilakukan melalui pemberdayaan masyarakat, berupa keterlibatan masyarakat dalam kegiatan promosi dengan ikut serta memberikan penyuluhan kesehatan perorangan dan lingkungan (Kementerian Kesehatan, 2017). Pengetahuan anak tentang cacingan yang kurang, faktor lingkungan dan personal hygiene yang rendah merupakan faktor resiko cacingan (Irawati, 2013; Saryono, 2010; Sudarianto, 2012; Tarwoto dan Wartonah, 2006)

Kebijakan ini selaras dengan penanganan kejadian stunting nasional. Angka prevalensi stunting Provinsi NTB tahun 2017 sebesar 37,2\% dan 39,3\% untuk Kabupaten Lombok Tengah (Kementerian Kesehatan, 2018b). Pemberian obat cacing dan program WASHED-Water, Sanitation, Hygiene Education and Deworming termasuk dalam kerangka intervensi sensitif dan spesifik penanganan stunting (Tim Teknis Gerakan Nasional Percepatan Perbaikan Gizi, 2017).

Pondok pesantren merupakan mitra potensial dalam penanganan cacingan dan stunting. Berdasarkan data Education Management Information System (EMIS) Kementerian Agama tahun pendataan 2015-2016 terdapat 28.984 pondok pesantren dengan 4.290 .626 santri di seluruh Indonesia. Jumlah pesantren di provinsi NTB sekitar 682 pondok (Kementrian Agama, 2017). Kondisi kesehatan pesantren sebagaimana dilansir Menteri Kesehatan periode 20142019, Prof. Dr.dr. Nila Djuwita Faried Anfasa Moeloek, Sp.M(K) memerlukan perhatian berbagai pihak terkait akses layanan kesehatan, perilaku sehat dan kesehatan lingkungan (Kementerian Kesehatan Republik Indonesia, 2018c).

Pesantren Sehat merupakan program potensial yang dirilis oleh Kementerian Kesehatan tahun 2019. Program ini bertujuan untuk meningkatkan pengetahuan dan kesadaran pentingnya kesehatan santri dan isu kesehatan nasional seperti Gerakan Masyarakat Hidup Sehat, eliminasi tuberkulosis, pencegahan stunting dan peningkatan cakupan imunisasi di kalangan pesantren. Secara teknis, Kementerian Kesehatan melibatkan organisasi masyarakat 
seperti Nahdlatul Ulama, Muhammadiyah dan Persatuan Islam. Upaya preventif-promotif berdasarkan Peraturan Menteri Kesehatan Republik Indonesia No. 163 Tahun 2013 dapat dilakukan di Pos Kesehatan Pesantren (Poskestren) sebagai bagian Upaya Kesehatan Bersumberdaya Masyarakat.

Untuk mendukung kebijakan dan program pemerintah tersebut, Program Studi Farmasi Fakultas Kedokteran Universitas Mataram telah bersinergi dengan berbagai pondok pesantren seperti Pondok Pesantren Nahdlatul Ulama Al Manshuriyah Ta'limusshibyan Sangkong Kabupaten Lombok Tengah, Pondok Pesantren Nahdlatul Wathan Hidayaturrahman Menggala Kabupaten Lombok Utara dan Pondok Pesantren Nahdlatul Ulama Ishlahuddiny Kabupaten Lombok Barat melalui kegiatan tugas akhir mahasiswa dan program pengabdian masyarakat.

Pondok Pesantren Ishlahuddiny merupakan salah satu pondok pesantren tertua yang didirikan pada tahun 1941 oleh Tuan Guru Haji Ibrahim Khalidy dan Tuan Guru Haji Mustafa Khalidy. Pendidikan madrasah berjalan secara formal klasikal terdiri atas tingkat Ibtidaiyah, Tsanawiyah dan Aliyah dilengkapi dengan Ma'had Aly dan Sekolah Tinggi Ilmu Dakwah Mustafa Ibrahim. Terkait layanan kesehatan, pondok ini belum memiliki Poskestren. Pemeriksaan kesehatan juga masih jarang dilakukan baik oleh pihak internal maupun eksternal pondok.

Berdasarkan gambaran mitra tersebut, pengabdian ini bertujuan untuk mengimplementasikan upaya penanggulangan cacingan melalui penyuluhan dan demonstrasi indikator PHBS pada Pondok Pesantren Nahdlatul Ulama Al-Ishlahuddiny Kediri, Kabupaten Lombok Barat. Pengabdian ini bermanfaat dalam mendukung upaya pencapaian target (Rencana Pembangunan Jangka Menengah Nasional Tahun 2015-2019; Peraturan Menteri Kesehatan No. 15 Tahun 2017; Visi, Misi, Tujuan dan Sasaran Universitas Mataram) dan berkontribusi dalam penanganan integrasi stunting-cacingan berbasis koordinasi lintas sektor khususnya pondok pesantren.

\section{Metode}

Program Pengabdian Masyarakat diselenggarakan Sabtu dan Minggu, 28-29 September 2019 di Ruang Aula Madrasah Ibtidaiyah (MI) Ishlahuddiny Kediri, Lombok Barat dan Laboratorium Biologi Farmasi Program Studi Farmasi Fakultas Kedokteran Universitas Mataram. Kegiatan ini melibatkan tim pengabdian masyarakat terdiri atas 4 dosen dan 2 mahasiswa berkoordinasi dengan 1 orang guru dan total sasaran 100 orang siswa MI kelas III -VI dengan rentang usia 8-12 tahun. Implementasi upaya penanggulangan cacingan di pesantren ini meliputi: survei pengetahuan, penyuluhan, pengukuran status antropometri, dan pemeriksaan status cacingan secara mikroskopis. Survei pengetahuan bertujuan untuk memperoleh data dasar mengenai pengetahuan dan perilaku santri terkait cacingan. Survei dilakukan dengan menggunakan wawancara semi terstruktur dan observasi dengan acuan instrumen dari Kementerian Kesehatan tahun 2012.

Instrumen mencakup aspek Perilaku Hidup Bersih dan Sehat (PHBS) terkait cacingan seperti kebiasaan defekasi, sumber air yang digunakan, kebiasaan Cuci Tangan Pakai Sabun (CTPS), kebiasaan alas kaki, kebiasaan jajan dan keadaan kuku. Selain PHBS, butir instrumen 
mencakup pengetahuan cacingan meliputi gejala, penularan, upaya preventif, dan pengobatan. Masing-masing butir pertanyaan memiliki butir pilihan. Tiap-tiap butir dalam lembar kuesioner selanjutnya dianalisa secara deskriptif.

Penyuluhan bertujuan memberikan alih pengetahuan mengenai pengetahuan cacingan dan pembimbingan PHBS sederhana di lingkungan pesantren. Metode ceramah dipilih selain karena efisiensi, sederhana dan menjangkau banyak peserta dalam waktu bersamaan (Presska, Salawati \& Astuti, 2012), juga sesuai dengan kebiasaan pengajaran klasikal di pesantren. Meski demikian, penggunaan media LCD dan pembimbingan berupa demonstrasi PHBS diharapkan memudahkan pemahaman siswa. Luaran yang diharapkan berupa partisipasi fungsional siswa (Pretty, 1995) dalam penyuluhan sebagai langkah awal pengembangan dalam komunitas pesantren.

Pengukuran status antropometri selain untuk menentukan data dasar status gizi siswa juga bagian implementasi indikator PHBS yakni pembiasaan pengukuran status gizi secara berkala. Tinggi badan dan berat badan siswa ditentukan menggunakan mikrotoa dan timbangan. Status gizi baik tunggal maupun komposit terdiri atas indeks tinggi badan terhadap usia dan indeks massa (Indeks TB/U dan IMT) ditentukan melalui aplikasi dr. Sapto Anthro.

Upaya surveilans dilakukan melalui penentuan status cacingan siswa melalui pemeriksaan mikroskopis telur cacing pada feses. Siswa diberikan form persetujuan setelah penjelasan (PSP) yang menyatakan kesediaan untuk mengumpulkan sampel feses. Form tersebut ditandatangani oleh orang tua/wali siswa. Selain itu, siswa dibimbing cara pengumpulan sampel setelah penyuluhan. Sampel feses dan PSP dikumpulkan keesokan harinya kemudian keberadaan dan spesies telur cacing ditentukan dengan teknik natif secara laboratoris. Angka prevalensi ditentukan selanjutnya setelah pemeriksaan. Tahapan pelaksanaan kegiatan pengabdian kepada masyarakat diilustrasikan pada bagan 1 .

Sebagai penutup kegiatan, hasil pelaksanaan berupa aspek pengetahuan dan PHBS yang perlu ditingkatkan oleh pondok pesantren, status antropometri dan status cacingan siswa dilaporkan kepada pengelola pondok pesantren. Berdasarkan hasil tersebut disampaikan juga rekomendasi yang relevan sehingga terdapat rencana tindak lanjut dalam rangka penanggulangan cacingan sebagai implementasi program pesantren sehat.

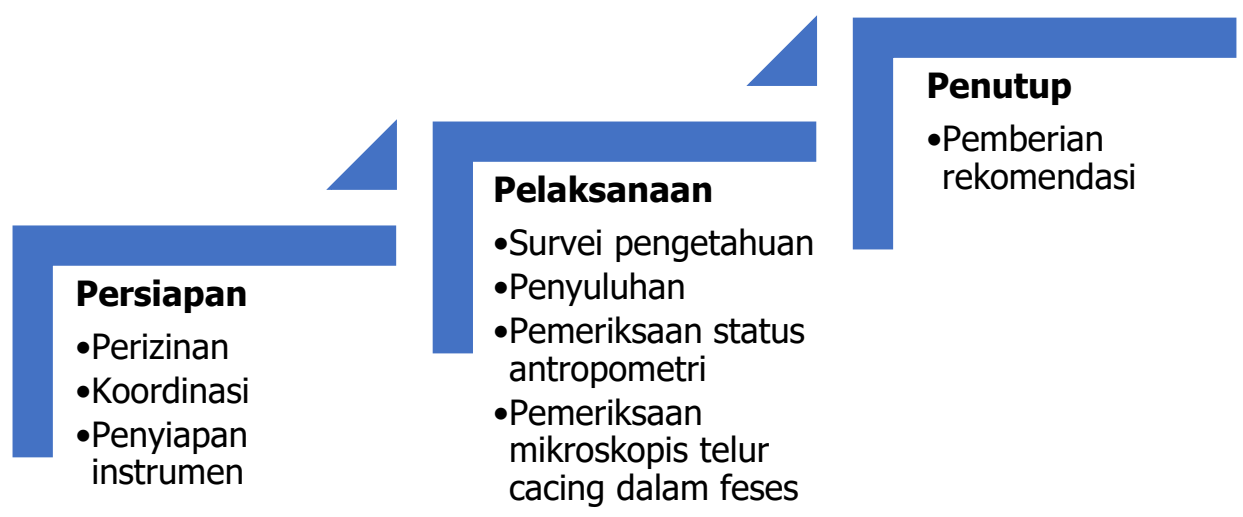

Bagan 1. Tahapan Pelaksanaan Kegiatan Pengabdian Kepada Masyarakat 


\section{Hasil dan Pembahasan}

Dokumentasi kegiatan dalam program pengabdian masyarakat yang dilakukan diilustrasikan pada Tabel 1.

Tabel 1. Dokumentasi Kegiatan Program Pengabdian Masyarakat Di MI Al-Ishlahuddiny
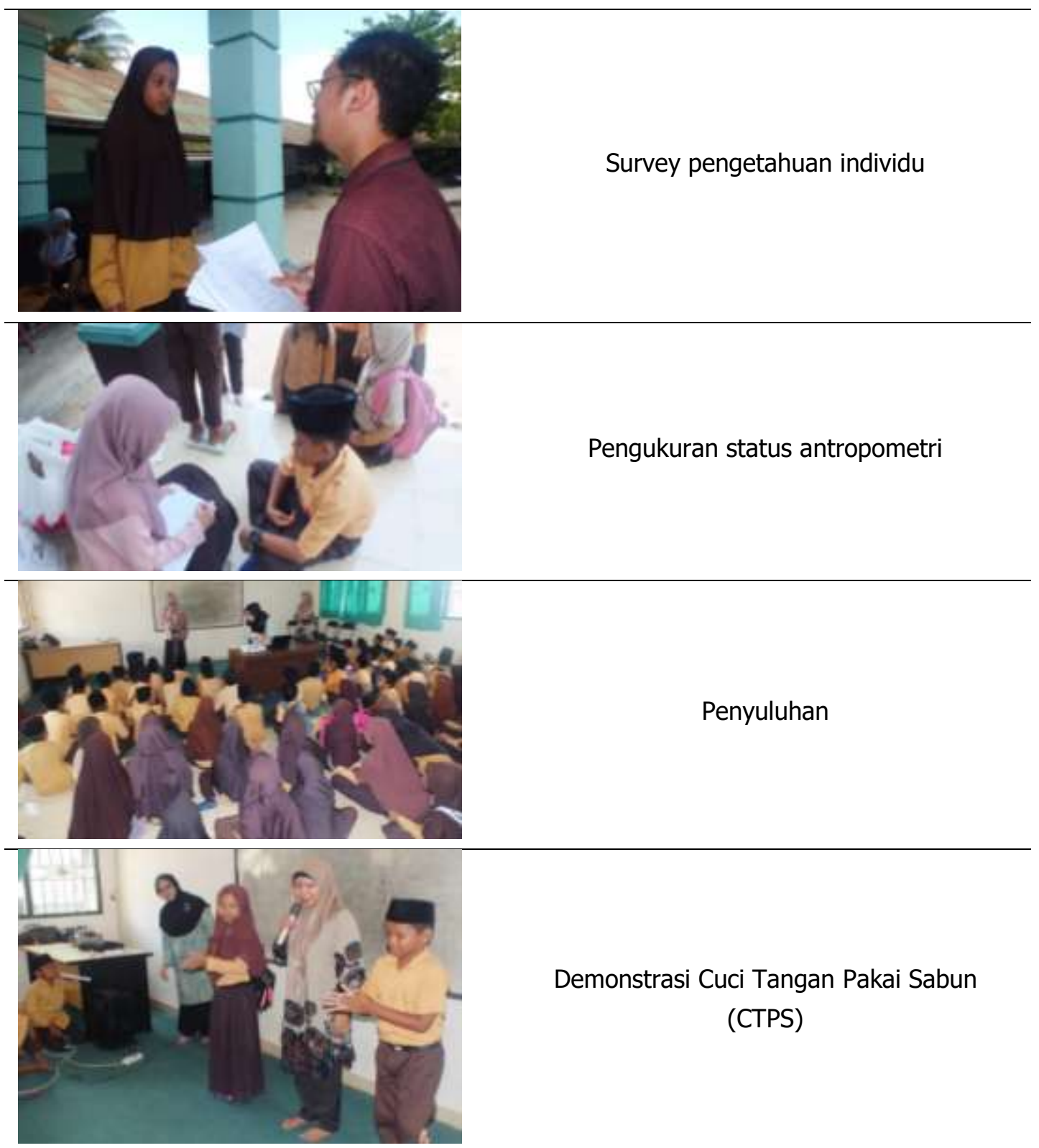

Demonstrasi Cuci Tangan Pakai Sabun

(CTPS)

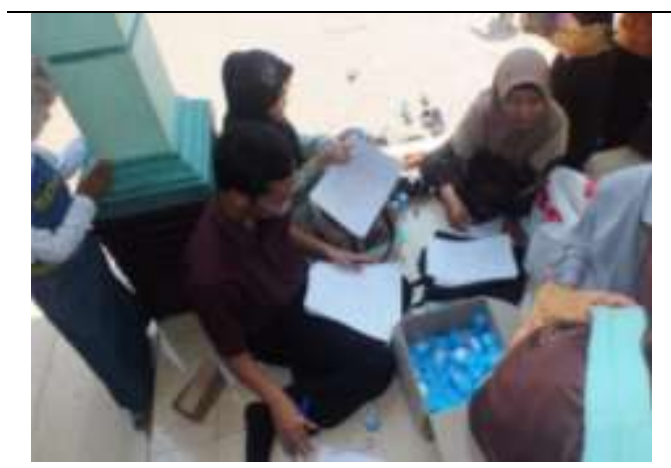

Pembagian form Persetujuan Setelah

Penjelasan (PSP) dan wadah sampel 


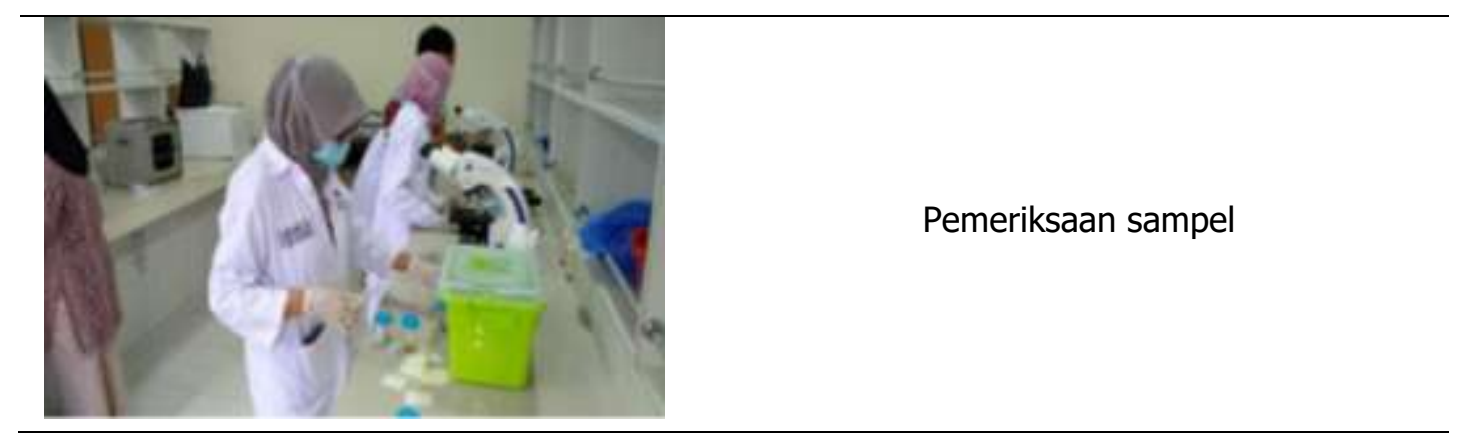

Daya dasar mengenai pengetahuan penting untuk dieksplorasi sebagai basis tindakan intervensi yang harus dilakukan. Pengetahuan seputar kesehatan akan berpengaruh kepada perilaku sebagai hasil jangka menengah dari pendidikan kesehatan sementara selanjutnya perilaku kesehatan akan berpengaruh kepada peningkatan indikator kesehatan sebagai keluaran (outcome) dari pendidikan kesehatan (Notoatmodjo, 2011). Hasil survei pengetahuan diilustrasikan dalam Tabel 2.

Tabel 2. Deskripsi Hasil Survei Pengetahuan Cacingan Siswa MI Ishlahuddiny

\begin{tabular}{|c|c|c|}
\hline No. & Aspek & Deskripsi \\
\hline 1 & Lokasi Kebiasaan BAB & $\begin{array}{l}95 \% \text { siswa buang air besar (BAB) di jamban mandiri } \\
5 \% \text { siswa BAB di sungai }\end{array}$ \\
\hline 2 & Sumber Air & $\begin{array}{l}70 \% \text { dari air ledeng (PAM) } \\
22 \% \text { dari air sumur } \\
8 \% \text { dari sumber lainnya (sumur pompa tangan, sungai, } \\
\text { sumur bor, dan air isi ulang) }\end{array}$ \\
\hline 3 & Kebiasaan Mencuci Tangan & $\begin{array}{l}39 \% \text { mencuci tangan sebelum makan dan sesudah } \mathrm{BAB} \\
34 \% \text { mencuci tangan sebelum makan } \\
10 \% \text { mencuci tangan setelah BAB } \\
9 \% \text { jawaban selain opsi (setelah makan, sebelum tidur, } \\
\text { setelah bermain, ketika tangan kotor) } \\
8 \% \text { jawaban kombinasi (tiga jawaban atau salah satu } \\
\text { opsi dan lainnya) }\end{array}$ \\
\hline 4 & CTPS Setelah Makan & $\begin{array}{l}81 \% \text { menggunakan sabun untuk cuci tangan setelah } \\
\text { makan } \\
19 \% \text { dengan air tanpa sabun untuk cuci tangan setelah } \\
\text { makan }\end{array}$ \\
\hline 5 & CTPS Setelah BAB & $\begin{array}{l}88 \% \text { menggunakan sabun untuk cuci tangan setelah } \\
\text { BAB } \\
12 \% \text { dengan air tanpa sabun untuk cuci tangan setelah } \\
\text { BAB }\end{array}$ \\
\hline 6 & $\begin{array}{l}\text { Penggunaan Alas Kaki Di Luar } \\
\text { Rumah }\end{array}$ & $\begin{array}{l}94 \% \text { bermain di luar rumah dengan alas kaki } \\
6 \% \text { bermain di luar rumah tanpa alas kaki }\end{array}$ \\
\hline 7 & Pengetahuan Gejala Cacingan & $\begin{array}{l}72 \% \text { tidak tahu gejala dan tanda cacingan } \\
15 \% \text { sakit perut/mencret sebagai gejala cacingan }\end{array}$ \\
\hline
\end{tabular}




\begin{tabular}{|c|c|c|}
\hline & & $\begin{array}{l}\text { 3\% jawaban selain opsi : lemas, perut buncit, nafsu } \\
\text { makan meningkat }\end{array}$ \\
\hline 8 & Cara Penularan Cacingan & $\begin{array}{l}65 \% \text { menjawab tidak tahu cara penularan cacingan } \\
21 \% \text { penularan melalui tangan atau kaki } \\
11 \% \text { penularan melalui makanan dan minuman } \\
3 \% \text { penularan melalui kotoran, batuk, dan bermain } \\
\text { dengan penderita lainnya }\end{array}$ \\
\hline 9 & Pencegahan Cacingan & $\begin{array}{l}\text { 42\% menjawab tidak tahu cara mencegah cacingan } \\
17 \% \text { menggunakan alas kaki di luar rumah } \\
9 \% \text { menjawab dengan minum obat cacing } \\
32 \% \text { opsi lainnya (makan bergizi, tidak BAB } \\
\text { sembarangan, tidak main tanah, cuci tangan, memotong } \\
\text { kuku, minum air sesudah dimasak, menjaga kebersihan } \\
\text { makanan) }\end{array}$ \\
\hline 10 & Lokasi Jajan & $\begin{array}{l}57 \% \text { jajan di kantin sekolah } \\
20 \% \text { jajan di luar sekolah } \\
21 \% \text { jajan di dalam dan luar sekolah } \\
2 \% \text { sarapan. }\end{array}$ \\
\hline 11 & Pemeriksaan Kuku & $\begin{array}{l}66 \% \text { kuku kotor } \\
34 \% \text { kuku bersih }\end{array}$ \\
\hline
\end{tabular}

Berdasarkan hasil survey di atas, terdapat beberapa hal yang menjadi perhatian:

1. Secara keseluruhan lokasi kebiasaan BAB telah sesuai, meski ada beberapa siswa yang menggunakan sungai. Hal ini dapat mempermudah transmisi cacingan via fekal-oral karena digunakan juga oleh beberapa siswa sebagai sumber air.

2. Dalam waktu cuci tangan, jawaban siswa tampak inkonsisten. Hal ini mungkin diakibatkan pertanyaan yang bersifat tertutup, sehingga perlu penggalian informasi lebih lanjut. Namun demikian terkait kekerapan penggunaan sabun masih rendah sehingga perlu pembiasaan.

3. Siswa sebagian besar sudah menggunakan alas kaki ketika bermain di luar rumah. Namun berdasarkan hasil wawancara, kekerapan penggunaan alas kaki masih rendah sehingga memerlukan pembiasaan lebih lanjut. Hal ini didukung dengan kebiasaan bermain siswa yang intens bersentuhan dengan tanah.

4. Pengetahuan siswa tentang cara penularan dan gejala cacingan masih rendah, berturutturut 65 dan 72\% tidak mengetahui hal tersebut.

5. Pengetahuan siswa tentang upaya pencegahan cacingan masih bervariasi. Dari jawaban terlihat $51 \%$ siswa tidak mengetahui dan misinformasi dengan pengobatan cacingan, sementara $49 \%$ siswa menjawab secara acak dan tersebar. Ada kemungkinan jawaban sesuai dengan apa yang diingat oleh siswa. Hal ini mendorong baik pihak sekolah maupun penyuluh untuk memberikan penekanan lebih intens terkait ragam upaya pencegahan cacingan.

6. Kebiasaan sarapan masih minim di kalangan siswa. Asupan makanan pagi masih didominasi dengan kebiasaan jajan. Untuk di sekitar sekolah, jajanan terbuka sehingga dapat mentransmisikan cacingan via fekal-oral. Adapun untuk kantin di dalam sekolah perlu 
dilakukan observasi lebih lanjut.

7. Kondisi PHBS yang perlu mendapatkan peningkatan: pemeriksaan kuku, penggunaan alas kaki, CTPS. Hal ini dapat didukung melalui koordinasi lintas sektor seperti integrasi dalam program MI, Poskestren dan Puskesmas dalam kegiatan penjaringan.

Setelah survey pengetahuan dilakukan, siswa mendapatkan penyuluhan. Penyuluhan meliputi aspek dasar cacingan dan PHBS terkait cacingan. Dalam penyuluhan aspek dasar cacingan, siswa dikenalkan berbagai gambar jenis cacing, aspek transmisi, pencegahan dan pengobatan sesuai dengan umur anak. Penyuluhan disertai dengan pemutaran media audiovisual untuk memperkuat retensi. Partisipasi fungsional mulai terlihat berupa tanya jawab siswa yang dilakukan setelah penyuluhan berkisar mengenai aspek biologis cacing, cacingan dan personal hygiene. Demonstrasi indikator PHBS sederhana seperti CTPS dilakukan oleh siswa sebagai internalisasi dan bukti pemahaman PHBS secara sederhana.

Berdasarkan hasil analisa survei antropometri pada 95 orang siswa (5 orang siswa izin pulang terlebih dahulu) dengan aplikasi dr Sapto Anthro diperoleh berikut: (1) Indeks TB/U : 4.21\% untuk sangat pendek ( $n=4$ siswa), 9.47\% pendek ( $n=9$ siswa), dan normal $86,31 \%$ ( $n=82$ siswa); (2) IMT diperoleh: $12.63 \%$ untuk sangat kurus ( $n=12$ siswa), $24.21 \%$ untuk kurus ( $n=23$ siswa), dan 63,15\% $(n=60)$ untuk normal. Indeks TB/U memberikan indikasi masalah gizi lalu/kronis sementara IMT dapat dipengaruhi oleh berbagai faktor saat ini termasuk infeksi sehingga menggambarkan masalah gizi akut.

Selain indeks tunggal, dapat juga ditentukan indeks komposit atau indeks gabungan. Penentuan indeks komposit berimplikasi pada tindakan yang akan diberikan. Indeks komposit diperoleh pada 6 orang siswa atau setara dengan $6,31 \%$ status gizi rendah dengan komposisi: $1.05 \%$ sangat pendek-sangat kurus ( $n=1$ siswa), $2.10 \%$ pendek-sangat kurus ( $n=2$ siswa) dan $3.15 \%$ pendek-kurus ( $n=3$ siswa). Sejumlah 2 orang siswa yang terinfeksi cacingan memiliki indeks komposit tunggal kurus dan komposit pendek-kurus. Secara kasar, dapat dinyatakan bahwa status cacingan mempengaruhi status gizi siswa.

Sampel feses kemudian dikumpulkan pada hari selanjutnya. Dari hasil pengumpulan diperoleh 38 sampel. Hal ini disebabkan berbagai faktor diantaranya banyak siswa yang kebiasaan BAB tidak teratur sehingga pada waktu pengumpulan tidak dapat memberikan sampel, keengganan orang tua untuk mengumpulkan sampel akibat rasa malu, dan jijik dalam melakukan pengambilan sampel. Pemeriksaan feses dilakukan secara mikroskopis dengan menggunakan metode natif atau eosin sebagai skrining awal sederhana.

Berdasarkan hasil pemeriksaan feses, diperoleh 3 orang dengan status cacingan (angka prevalensi 0.7\%). Infeksi bervariasi baik tunggal (Hymenolepis sp, Ascaris sp) maupun komposit (Ascaris sp dan Trichuris sp). Hasil pemeriksaan berupa penampang mikroskopis telur masingmasing spesies (ditunjukkan dengan panah penunjuk) pada perbesaran 40x diilustrasikan dalam gambar 1. 


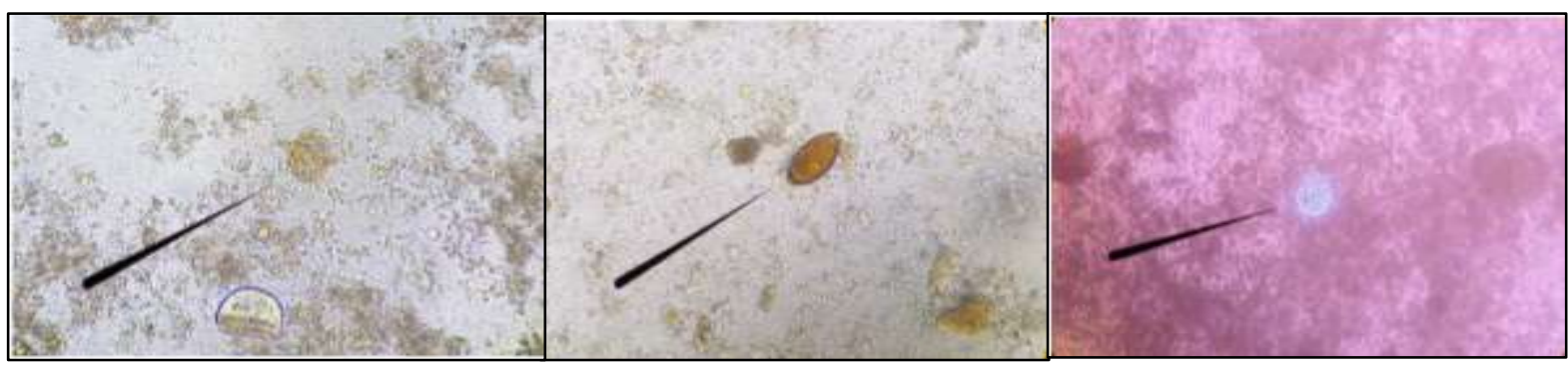

Gambar 1. Telur cacing dalam feses melalui pemeriksaan natif. Dari kiri ke kanan: Ascaris $s p$, Trichuris sp dan Hymenolepis sp (pewarnaan eosin).

Berdasarkan hasil pelaksanaan kegiatan pengabdian kepada masyarakat yang telah dilakukan, rekomendasi tim pengabdian kepada pengelola adalah sebagai berikut: (1) tindakan pengobatan melalui pemberian antelmintik dilakukan terhadap santri yang terinfeksi cacingan, (2) tindakan pencegahan dapat dilakukan melalui program sederhana yang terintegrasi dengan proses belajar mengajar seperti pemeriksaan kuku, dan (3) pendirian dan pemberdayaan Poskestren di lingkungan Pondok Pesantren Nahdlatul Ulama Ishlahuddiny bekerja sama dengan Puskesmas Kediri.

\section{Kesimpulan}

Upaya penanggulangan cacingan berupa penyuluhan dan demonstrasi indikator Perilaku Hidup Bersih dan Sehat (PHBS) telah diimplementasikan pada sasaran siswa Pondok Pesantren Nahdlatul Ulama Al-Ishlahuddiny Kediri, Kabupaten Lombok Barat. Partisipasi fungsional siswa ditunjukkan dalam indikator PHBS sederhana terdiri atas Cuci Tangan Pakai Sabun, penggunaan alas kaki, pengukuran berat dan tinggi badan secara berkala dan pemeriksaan telur cacing.

\section{Referensi}

Anuar, T.S., Salleh, F.M. \& Moktar, N. (2014). Soil-Transmitted Helminth Infections and Associated Risk Factors In Three Orang Asli Tribes In Peninsular Malaysia. Scientific Reports. 4(4101),1-6 Irawati. (2013). Hubungan Personal Hygiene Dengan Cacingan Pada Anak Di Wilayah Kerja Puskesmas Tamangapa Antang Makassar. Skripsi: Universitas Islam Negeri Alauddin Makassar.

Kementerian Agama. (2017). Berita Pendidikan Islam: Mengembangkan Kestrategisan Pondok $\begin{array}{lllll}\text { Pesantren } \quad \text { (Artikel } & \text { Web). } & \text { Di }\end{array}$ pendis. kemenag.go.id/index.php?a=detil\&id=9405\#.XiiDX9nmiDY

Kementerian Kesehatan Republik Indonesia. (2012). Pedoman Pengendalian Kecacingan. Jakarta: Kementerian Kesehatan Republik Indonesia.

Kementerian Kesehatan Republik Indonesia. (2017). Peraturan Menteri Kesehatan Republik Indonesia No 15 Tahun 2017 Tentang Penanggulangan Cacingan. Jakarta: Kementerian Kesehatan Republik Indonesia.

Kementerian Kesehatan Republik Indonesia. (2018a). Laporan Survei Prevalensi Kecacingan Pada Anak SD/MI, Balita, dan Ibu Hamil di Kabupaten Lombok Tengah, NTB. Surabaya: Direktorat Jenderal Pencegahan dan Pengendalian Penyakit, Balai Besar Teknik Kesehatan Lingkungan Dan Pengendalian Penyakit Kementerian Kesehatan Republik Indonesia.

Kementerian Kesehatan Republik Indonesia. (2018b). Penggerakan Pelaksanaan Kegiatan Pembinaan Gizi Dalam Upaya Pencegahan dan Penanggulangan Stunting di Provinsi Nusa Tenggara Barat. Disampaikan oleh Direktorat Gizi Masyarakat Direktorat Jenderal Kesehatan 
Masyarakat Kementerian Kesehatan Republik Indonesia dalam Rapat Kerja Kesehatan Daerah Provinsi Nusa Tenggara Barat di Mataram pada 19 April 2018.

Kementerian Kesehatan Republik Indonesia. (2018c). Generasi Indonesia Harus Sehat, Agar Indonesia Menjadi Bangsa Maju dan Kuat (Artikel Web). Diakses di https://www.depkes.go.id/article/view/18111900007/generasi-indonesia-harus-sehat-agarindonesia-jadi-bangsa-maju-dan-kuat-.html

Notoatmodjo, S. (2011). Kesehatan Masyarakat IImu Dan Seni. Jakarta: PT. Rineka Cipta.

Presska, C., Salawati, T. \& Astuti, R. (2012). Pengaruh Penyuluhan Kesehatan Tentang Kecacingan Terhadap Pengetahuan Dan Sikap Siswa Madrasah Ibtidaiyah An-Nur Kelurahan Pedurungan Kidul Kota Semarang. Jurnal Promosi Kesehatan Indonesia, 72): 1-7

Pretty, J. N. (1995). Participatory Learning For Sustainable Agriculture. World Development, 23(8): $1247-1263$.

Saryono. (2010). Catatan Kuliah Kebutuhan Dasar Manusia. Yogyakarta: Nuha Medika.

Sudarianto. (2012). Buruknya Sanitasi Lingkungan Masyarakat Berdampak Buruk Terhadap Kematian Anak (Artikel Web). Diakses di http://dinkes.sulsel.go.id/new/index.php?option=com_content\&task=view\&id=852\&Itemid=1

Tarwoto \& Wartonah. (2006). Kebutuhan Dasar Manusia Dan Proses Keperawatan. Jakarta: Salemba Medika.

Tim Teknis Gerakan Nasional Percepatan Perbaikan Gizi. (2017). Peta Jalan Implementasi Gerakan Nasional Percepatan Perbaikan Gizi 2017-2019. Jakarta: Bapennas. 